\section{OPEN ACCESS}

Edited by:

Suzie Chen,

Rutgers, United States

Reviewed by:

Jian Sun,

Tianjin University, China Triantafyllos Stylianopoulos, University of Cyprus, Cyprus

*Correspondence:

Yong Tang tyjaq7926@163.com Ning Deng tdengn@jnu.edu.cn

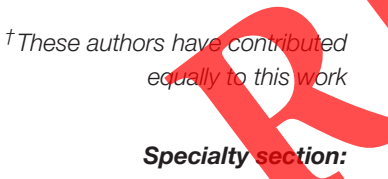

This article was submitted to Cancer Molecular Targets and

Therapeutics,

a section of the journal

Frontiers in Oncology

Received: 14 March 2020 Accepted: 11 June 2020 Published: 17 July 2020

Citation:

Zhang L, Deng Y, Zhang Y, Liu C, Zhang S, Zhu W, Tang Y and Deng N (2020) The Design, Characterizations, and Tumor Angiogenesis Inhibition of a Multi-Epitope Peptibody With bFGFNEGFA. Front. Oncol. 10:1190. doi: 10.3389/fonc.2020.01190

\title{
The Design, Characterizations, and Tumor Angiogenesis Inhibition of a Multi-Epitope Peptibody With bFGF/VEGFA
}

Ligang Zhang ${ }^{\dagger}$, Yanrui Deng ${ }^{\dagger}$, Yinmei Zhang, Chunyan Liu, Simin Zhang, Wenhui Zhu, Yong Tang* and Ning Deng*

Department of Biology, Guangdong Province Engineering Research Center for Antibody Drug and Immumoassay, Jinan University, Guangzhou, China

Tumor angiogenesis is dependent on growth factors, and inhibition of their pathways is one of the promising strategies in cancer therapy. However, resistance to single pathway has been a great concern in clinical trials so that it necessitates multiple targetable factors for developing tumor angiogenesis inhibitors. Moreover, the strategy of Fc fusion protein is an attractive platform for hovel peptide agents, which gains increasing importance with FDA approval because of better immunogenicity and stability. Here, we applied the Fc fusion protein concept to bFGFNEGFA pathways and designed a multi-epitope Peptibody with immunogenic peptides derived from human bFGF and VEGFA sequences. Immunization with Peptibody could elicit high-titer anti-bFGF and anti-VEGFA antibodies, activate $T$ cells, and induce Th1/Th2-type cytokines. In in vitro experiments, the isolated anti-Peptibody antibody inhibited the proliferation and migration of A549 cells and human umbilical vein endothelial cells (HUVECs) by decreasing the MAPK/Akt/mTOR signal pathways. In the murine tumor model, pre-immunization with Peptibody suppressed the tumor growth and neovascularization of lung cancer by decreasing the production of bFGFNEGFA/PDGF, the MAPK/Akt/mTOR signal pathways, and the activation of suppressive cells in tumor sites. Further, the biological characterizations of the recombinant Peptibody were investigated systematically, including protein primary structure, secondary structure, stability, and toxicity. Collectively, the results highlighted the strategy of bFGFNEGFA pathways and Fc fusion protein in suppressing tumor progression and angiogenesis, which emphasized the potential of multiple targetable factors for producing enduring clinical responses in tumor patients.

Keywords: bFGF, VEGFA, Fc domain, peptibody, tumor angiogenesis

\section{INTRODUCTION}

The formation of blood vessels is critical not only for normal development but also for tumorigenesis and metastasis (1). Once solid tumors grow beyond a few millimeters, the angiogenic program is turned on to transport nutrients, oxygen, and metabolins, making tumor growth uncontrolled (2). This complex process requires proliferation, migration, and structural 
modification of endothelial cells, which are regulated by proangiogenic factors, such as basic fibroblast growth factor (bFGF) and vascular endothelial growth factor A (VEGFA) (3). Further, either alone or in combination, these two factors stimulate proteases and plasminogen activators in tumor tissues to degrade the basement membrane, which promotes tumor metastasis and endothelial cells recruitment for neovascularization (4). In addition, bFGF and VEGFA can synchronize platelet-derived growth factor (PDGF) and its receptor synergistically to facilitate blood vessel formation by modulating their expression and activation (5). Aberrant expression of bFGF and VEGFA are implicated in a broad range of solid tumors (6-8). These endogenous growth factors work as primary regulators in tumor progression and angiogenesis through autocrine and paracrine activation of their cognate receptors (9). Since solid tumor is highly vascularized, the strategy of anti-angiogenesis is more attractive. bFGF and VEGFA have been become the popular targetable genes with FDA approval, such as the inhibition of growth factors, receptors, and intracellular kinases (1015). Nonetheless, resistance to single pathway often occurs in the presence of activated alternative growth factors in clinical therapy, followed by a compensatory restoration of tumor growth (16). In order to produce enduring clinical responses in cancer patients, the strategy targeting multiple factors might be a feasible improvement.

Fc fusion protein, in which Fc domain of IgG isotypes is joined to recombinant protein, is considered as a promising platform for novel peptide agents (17). Drugs derived from peptide often suffer from short serum half-life owing to their low molecular mass and fast renal clearance (18). In contrast, Fc fusion protein generated from the genetic linkage of effector moiety (cytokines or antibody fragments) and Fc domain (human IgG1) is believed to be effective in human therapy, as exemplified by Etanercept (Enbrel), a TNFR2-Fc fusion protein that reduces TNF in rheumatoid arthritis (RA) (19). Indeed, it can induce potent physiological responses through the interaction with $\mathrm{Fc}$ receptor. The binding of Fc domain and neonatal Fc receptor (FcRn) expressed in epithelial, endothelial, and leukocyte cells protects the effector protein from lysosomal breakdown, increasing the half-life and therapeutic activity (20). Abatacept (Orencia), a CTLA-4-Fc fusion protein that abrogates T cell activation in RA, has a half-life of more than 10 days (21). The binding capability to $\mathrm{Fc}$ gamma receptor $(\mathrm{Fc} \gamma \mathrm{R})$ family can trigger certain Fc-mediated effector functions, such as complement-dependent cytotoxicity, antibody-dependent cell-mediated cytotoxicity, and modulations of other immune cells (22). Other properties such as solubility and stability have considerable improvements with Fc domain (23). Additionally, this technology facilitates the downstream purification, allowing the use of Protein A chromatography, with high affinity to Fc domain (24). Aflibercept (Eylea and Zaltrap) is a soluble recombinant $\mathrm{Fc}$ fusion protein containing extracellular domains of VEGFR1 and VEGFR2 (12). Consequently, Fc fusion protein is now well-established as therapeutics with FDA approval, and such strategy for novel peptide agents will gain increasing importance in cancer therapy (25). However, Fc domain is also a foreign antigen, so the immunogenicity of $\mathrm{Fc}$ domain in the Fc fusion protein should be included.
In this study, we applied the Fc fusion protein concept to both bFGF and VEGFA pathways and investigated the contribution of this anti-angiogenesis strategy in tumor therapy. The recombinant Fc fusion protein (Peptibody) we designed was composed of three human immunogenic bFGF peptides, three human immunogenic VEGFA peptides, and a human IgG1 Fc domain, which were derived from bioinformatic prediction and phage display. Above all, the immunogenicity of Peptibody should be evaluated systematically in mice, including whether it could elicit specific humoral and cellular immune responses and the activation of relevant cytokines. Next, we examined the inhibitory effects and mechanisms of Peptibody on tumor progression and angiogenesis, using lung cancer cell line A549 and vascular cell line HUVECs (human umbilical vein endothelial cells) in vitro experiments and murine tumor model of Lewis lung cancer (LL-2). Further, we enhanced our understanding of detailed biological characterizations of the recombinant Peptibody, including protein primary structure, secondary structure, stability, and toxicity. We hoped that the strategy of multiple targetable factors and Fc fusion protein would provide a broad-acting therapeutic modality for tumor angiogenesis inhibition.

\section{MATERIALS AND METHODS \\ Construction of pET-28a-bFGF/VEGFA-Fc Plasmid and the Expression and Purification Tests}

The immunogenic peptides of human bFGF and VEGFA
were obtained from a phage peptide library scanning and
bioinformatic analysis according to the prediction by Saha
et al. and El-Manzalawy et al. (26-28). The oligonucleotide
fragments of bFGF/VEGFA-Fc (human IgG1) with linkers were
synthesized by Sangon Biotech (Shanghai, China) and inserted
into the vector pET-28a by restriction enzymes Nhel, BamHI, and
Xhol, creating pET-28a-bFGF/VEGFA-Fc (pET-28a-Peptibody).
After validation by restriction enzymes and PCR assays, the
recombinant plasmid was expressed in E. coli BL21 (DE3)
and induced with $0.1 \mathrm{mM}$ IPTG in the mid-log phase at
$28^{\circ} \mathrm{C}$. The recombinant Peptibody was purified by gradient
NaCl-PB solution using cation-exchange and hydrophobic
chromatography. The peptide candidates and primers were
presented in Table S1.

\section{Cell Culture}

Human lung cancer cells A549, HUVECs, and murine Lewis lung cancer cells LL-2 were available in our laboratory. Cells were cultured in DMEM (Gibco, Langley, OK, USA) supplemented with $10 \%$ fetal bovine serum (FBS, Gibco), $100 \mathrm{U} / \mathrm{ml}$ penicillin (Gibco), and $100 \mu \mathrm{g} / \mathrm{ml}$ streptomycin (Gibco) at $37^{\circ} \mathrm{C}$ in a humidified atmosphere of $5 \% \mathrm{CO}_{2}$. If necessary, cells were activated with $10 \mathrm{ng} / \mathrm{ml} \mathrm{bFGF}$.

\section{Mice and Immunization}

The BALB/c and C57BL/6 mice (female, 6 weeks) were purchased from the Experimental Animals Center of Southern Medical University in Guangzhou, China. The mice were housed in 
specific pathogen-free environment and the treatment of animals was approved by the Institutional Animals Care and Use Committee on animal research in Jinan University, Guangzhou, China. Every 2 weeks, the mice were injected subcutaneously (s.c.) with Peptibody (100 $\mu \mathrm{g} /$ mouse), the recombinant Fc domain (100 $\mu \mathrm{g} /$ mouse), and the same volume of PBS for three times, respectively. Four weeks later, mice were sacrificed and organs and blood were extracted.

\section{Enzyme-Linked Immunosorbent Assay (ELISA)}

The human bFGF (\#P09038, R\&D Systems, Minneapolis, MN, USA) and VEGFA (\#AAA36804, R\&D Systems) were dispensed into 96 -well plates ( $50 \mathrm{ng} /$ well, overnight, $4^{\circ} \mathrm{C}$ ). After $5 \%$ nonfat milk blocking $(1 \mathrm{~h})$, the plates were incubated with serially diluted sera from Peptibody and PBS-immunized mice. After 45 -min incubation $\left(37^{\circ} \mathrm{C}\right)$ of HRP-conjugated goat anti-mouse IgG (1:2000, \#D110087, Sangon Biotech, Shanghai, China), the absorbance at $450 \mathrm{~nm}$ was read by a microplate reader (BioTek Instruments, Winooski, VT, USA). The antibody titers were defined as the reciprocal of serum dilution. PBS and the recombinant Fc domain served as the control. The antibody subtypes were measured by Isotyping ELISA Kit (\#SEK003, Sino, Beijing, China). The expression levels of IFN- $\gamma$ and IL-2/4/6 in the spleen and serum were determined by pre-coated plates ELISA Kit (\#430808, \#431008, \#431108, \#431308, BioLegend, San Diego, CA, USA). The expression level of histamine in the serum and the binding activity of Peptibody were detected by double-antibody sandwich-ELISA (ds-ELISA).

\section{Flow Cytometry (FCM)}

For $\mathrm{T}$ cell analysis, the splenocytes $\left(5 \times 10^{5} /\right.$ well $)$ were incubated with PE-labeled anti-mouse CD4 (\#100407, BioLegend) and Percp-labeled anti-mouse CD8 (\#100731, BioLegend) antibodies. For cell cycle analysis, A549 cells (1 × $10^{5}$ /well) were incubated with $200 \mu \mathrm{g} / \mathrm{ml}$ anti-Peptibody antibady, fixed with $70 \%$ ethanol, and stained with PI. Irrelevant IgG, anti-Fc antibody, and antifull-length bFGF antibody served as the control. The labeled splenocytes and stained A549 cells were detected by FACSCalibur flow cytometer $\mathrm{BD}$ Biosciences, CA, USA). T cells were calculated by FlowJo software (Flow o LLC, OR, USA) and cell cycle distribution was analyzed by ModFit LT software (Verity Software House, ME, USA).

\section{Cell Viability}

A549 cells and HUVECs $\left(1 \times 10^{3} /\right.$ well $)$ were seeded into 96well plates and anti-Peptibody antibody was added at increasing concentrations, from 25 to $400 \mu \mathrm{g} / \mathrm{ml}$. Cells were cultured for a further $72 \mathrm{~h}$ and cell viability was determined using CCK-8 kit (10 $\mu$ l, \#CK04, Dojindo, Kumamoto, Japan). The absorbance at $450 \mathrm{~nm}$ was read by a microplate reader. Irrelevant IgG, anti-Fc antibody, and anti-full-length bFGF antibody served as the control.

\section{Western Blotting}

Cells were lysed with RIPA buffer (\#P0013, Beyotime, Jiangsu, China) containing protease and phosphatase inhibitors. Protein concentrations were measured by BCA kit (Thermo Scientific, San Jose, CA, USA). Each sample of $20 \mu \mathrm{g}$ protein was separated on 10\% SDS-PAGE gels and blotted onto PVDF membranes (\#IPVH00010, Millipore, Bedford, MA, USA). Primary antibodies used were anti-mTOR (1:1000, \#2983), anti-Akt (1:1000, \#4691), anti-p-Akt (Ser473, 1:2000, \#4060), anti-MAPK (1:1000, \#4695), anti-p-MAPK (Thr202/Tyr204, 1:2000, \#4370), and anti-GAPDH (1:1000, \#5174) (Cell Signaling Technology, Danvers, MA, USA); anti-VEGFA (1:10,000, \#ab52917, Abcam, Cambridge, UK); and anti-His (1:1000, \#D110002, BBI Life Sciences, Shanghai, China). Secondary antibody used was HRP-conjugated goat anti-rabbit IgG (1:1000, \#7074, Cell Signaling Technology). Immunoreactivity detection was performed using super ECL plus (\#WBKLS0100, Millipore) and Gel Documentation System (Bio-Rad, Hercules, CA, USA). GAPDH served as loading control and the signal intensities were quantified by ImageJ software (NIH, Bethesda, MD, USA).

\section{Wound-Healing Assay}

Cells $\left(3 \times 10^{5}\right.$ cells/well $)$ were seeded in 6-well plates and incubated with $200 \mu \mathrm{g} / \mathrm{ml}$ anti-Pêptibody antibody for a further $24 \mathrm{~h}$. The monolayer cells were scraped in a straight line and washed. Photographs of the scratches were taken at 0,12 , and $24 \mathrm{~h}$ using an inverted microscope (Olympus, Tokyo, Japan). The area without cells of the efined site along each scratch was measured by ImageJ software and given an average of all measurements. Irrelevant IgG, anti-Fc antibody, and anti-fulllength bFGF antibody served as the control.

\section{atrigel Invasion Assay}

Cells $\left(2 \times 10^{5}\right.$ cells/well $)$ suspended in $100 \mu \mathrm{l}$ of basal medium were seeded into the upper transwell chambers (\#353097, BD Bioscience, San Jose, CA, USA) coated with Matrigel (\#356234, BD Bioscience), and $700 \mu \mathrm{l}$ of medium containing $10 \% \mathrm{FBS}$ was plated into the bottom. After incubating with $200 \mu \mathrm{g} / \mathrm{ml}$ anti-Peptibody antibody for $24 \mathrm{~h}$, the cells were fixed with $4 \%$ paraformaldehyde and stained with $0.1 \%$ crystal violet. The cells on the surface of upper chamber were removed. The migrated cells were photographed by inverted microscope and counted in five random fields. Irrelevant IgG, anti-Fc antibody, and anti-fulllength bFGF antibody served as the control.

\section{Mouse Model and Survival Study With LL-2 Cells}

As described above, the C57BL/6 mice $(n=7)$ were immunized with Peptibody, human full-length bFGF (R\&D Systems) as a positive control and PBS as a negative control. Four weeks later, mice were inoculated with LL- 2 cells $\left(2 \times 10^{6} /\right.$ mouse $)$ under the left front flank. Tumor growth was measured by a caliper and tumor volume was calculated using the formula: Volume $=a \times b^{2} / 2$ ( $a$, the longer diameter; $b$, the shorter one). After sacrifice, tumors were stripped and weighed. Animal survival was determined on the basis of tumor sizes reaching the longest diameters allowable $(20 \mathrm{~mm})$. To assess the effects of Peptibody on tumor growth, the tumor volumes at different time points were subjected to mixed-effects models for repeatedmeasures ANOVA. 


\section{Immunofluorescence (IF) and Hematoxylin-Eosin (HE) Staining}

Tumor tissues from the mouse model were fixed in $4 \%$ paraformaldehyde and embedded in paraffin. After deparaffinization, the sections were incubated with $10 \mathrm{mM}$ sodium citrate buffer $(\mathrm{pH} 6.0)$ and $3 \% \mathrm{H} 2 \mathrm{O} 2$ to repress the endogenous peroxidase activity, followed by 5\% BSA and $0.05 \%$ Triton X-100 blocking treatment. For IF assay, primary antibodies used were anti-CD31 (1:20, \#ab28364), anti-LYVE-1 $(5 \mu \mathrm{g} / \mathrm{ml}$, \#ab14917), anti-bFGF (1:200, \#ab8880), and antiVEGFA (1:250) (Abcam); anti-PDGF (1:200, \#GB11261), anti-IL-10 (1:200, \#GB11108), and anti-TGF- $\beta$ (1:200, \#GB14152) (Servicebio, Wuhan, China); anti-mTOR (1:200), anti-p-Akt (1:400), anti-p-MAPK (1:200), and anti-CD11b (1:800, \#17-0112-8, eBioscience, San Diego, CA, USA); and anti-EGF (1:200, \#sc-374255, Santa Cruz Biotechnology, Santa Cruz, CA, USA). Cell nuclei were visualized with DAPI $(5 \mathrm{ng} / \mathrm{ml}$, Invitrogen, New York, NY, USA) and fluorescence was collected by a fluorescence microscope (Olympus). For HE staining, the sections were stained with $\mathrm{HE}$, and the images were captured by an inverted microscope.

\section{Liquid Chromatography-Mass Spectrometry (LC-MS)}

The mass spectrometer used was Q Exactive (Thermo Scientific). For sequencing and peptide mapping, the data were processed by BiopharmaLynx 1.3 software. For molecular weight (MW), the data were calculated through deconvolution by ProMass for XcaliburTM software.

\section{Circular Dichroism (CD)}

Using Chirascan Plus V100 spectrometer (Applied Photophysics, Leatherhead, Surrey, UK), the CD spectra of Pept recorded in a cylindrical quartz cuvette at room temperature. The recorded spectra were analyzed by Pro-Data Viewer in the model of Milli-Degress.

\section{Tm and Tagg}

OPTIM instrument (Unchained Labs, San Erancisco, CA, USA) was used to detect the thermal unfolding transition mid-point temperature (Tm) and aggregation onset temperature (Tagg). The linear ramp of temperature $\left(15-95^{\circ} \mathrm{C}\right)$ was increased at $10^{\circ} \mathrm{C} / \mathrm{min}$. The intrinsic tryptophane fluorescence and static light scattering (SLS) at 266 and $475 \mathrm{~nm}$ were calculated and plotted.

\section{Statistical Analysis}

The experiments were repeated three times at least and the data were presented as mean \pm standard deviation ( $S D$, error bars). The statistical significance of differences between experimental groups was analyzed by SPSS 19.0 software and Student's $t$-test. $P$ $<0.05$ was considered to be statistically significant.

\section{RESULTS}

\section{Design of the Recombinant Peptibody and the Expression and Purification Tests}

Six peptide candidates targeting $\mathrm{B}$ cell and $\mathrm{T}$ cell epitopes were selected to construct the recombinant Peptibody fusion protein with human IgG1 Fc domain (Table S1). Three bFGF epitope peptides were used: AMKEDGRLLASK (75-86, b1), IHPDGRVDGVREKS (34-47, b2), and RLESNNYNTYRSRKYTS (97-113, b3). The three VEGFA epitope peptides used were QKRKRKKSRYKS (331-342, V1), RPKKDRARQ EKKS (311-323, V2), and VASAVFYSALVE (phage peptide library, V3). The synthesized sequences bFGF/VEGFA-Fc were inserted into pET-28a by restrictions enzymes Nhel, BamHI, and Xhol (Figure 1A). The expression vector $\mathrm{pET}$-28a-Peptibody was identified by restriction digestion and transformed into E. coli BL21 (DE3). The Peptibody strains were induced with $0.1 \mathrm{mM}$ IPTG (Figure 1B). The target protein was purified by gradient $\mathrm{NaCl}-\mathrm{PB}$ solution using cation-exchange and hydrophobic chromatography (Figure 1C).

\section{Peptibody Elicited Superior Immune Responses in Mice}

The BALB/c mice were injected s.c. with Peptibody (100 $\mu \mathrm{g} /$ mouse), the recombinant Fc domain (100 $\mu \mathrm{g} /$ mouse), and PBS, respectively. After sacrifice, blood was extracted and the antibodies were purified by Protein $G$ affinity chromatography (Figure 2A). To identify the immune signatures of Peptibody, the sera and spleens were collected to analyze the antibody titers, T cell activation, and relevant cytokines. The titers of antibFGF, anti-VEGFA, and anti-Fc antibodies were about 1:16,000, $1: 2000$, and 1:4000, respectively, while most of the antibody subtypes were IgG (Figures 2B,C). The proportions of $\mathrm{CD}^{+}$ $\mathrm{T}$ and $\mathrm{CD}^{+} \mathrm{T}$ cells were increased by $10.28 \pm 1.16 \%$ and $3.32 \pm 0.91 \%$ (Figure 2D). Further, the Th1/Th2 cell-related cytokines, including IFN- $\gamma$ and IL-2/4/6 were obviously upregulated (Figure $2 \mathrm{E}$ ). As a foreign antigen, immunization with Fo domain alone could also activate some immune responses, but the signatures were weaker than Peptibody (Figures 2B,D). Collectively, Peptibody showed superior immune signatures including specific $\mathrm{B}$ cell and $\mathrm{T}$ cell responses and relevant cytokine activation, which might be used as a potential agent for tumor treatment.

\section{Anti-Peptibody Antibody Inhibited the Proliferation, Migration, and Invasion of A549 Cells and HUVECs}

To investigate the inhibitory effects of anti-Peptibody antibody on tumorigenesis and angiogenesis, assays of CCK-8, signal pathway, cell cycle, wound healing, and Matrigel invasion were conducted in vitro. The results showed that the proliferation of A549 cells and HUVECs was obviously suppressed in a dose-dependent manner, with inhibition rates of $65.74 \pm 2.95 \%$ and $24.17 \pm 8.45 \%$ at $400 \mu \mathrm{g} / \mathrm{ml}$ (Figure 3A, Figure S1A). The MAPK/Akt/mTOR signal pathways were down-regulated in a dose- and time-dependent manner (Figure 3B, Figure S1B). The DNA replication of A549 cells was inhibited and cell cycle was arrested at the G1 phase (Figure 3C). The migration and invasion of A549 cells and HUVECs were obviously inhibited, with inhibition rates over 60\% (Figures 3D-F, Figures S1C,D). Moreover, the irrelevant IgG and anti-Fc antibody did not show any inhibitory effects while the inhibition of anti-Peptibody antibody was stronger than 
A

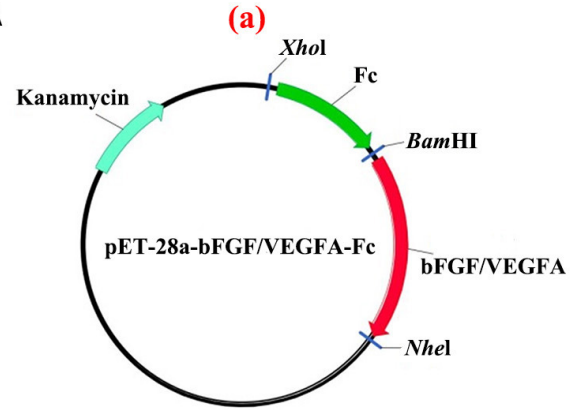

B

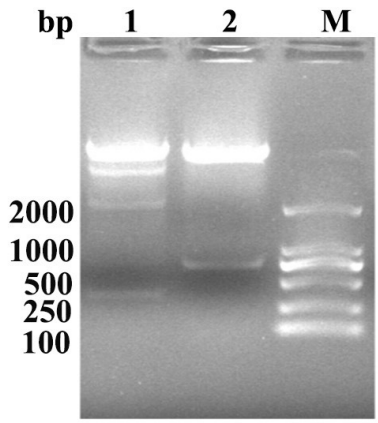

kIDa

kDa 1
180

100
75

60

45

35

25

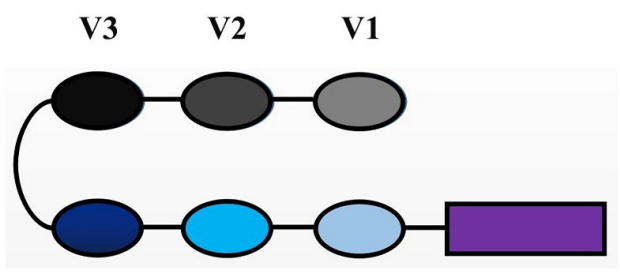

b1

b2

b3

Fc

(b)

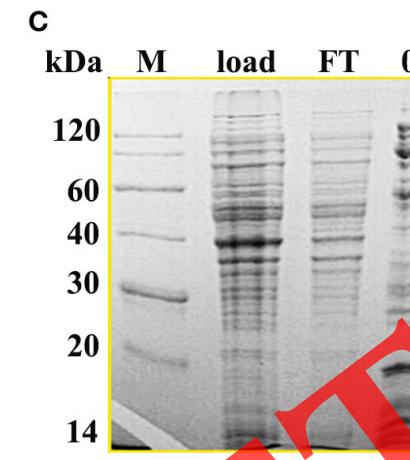

(a)
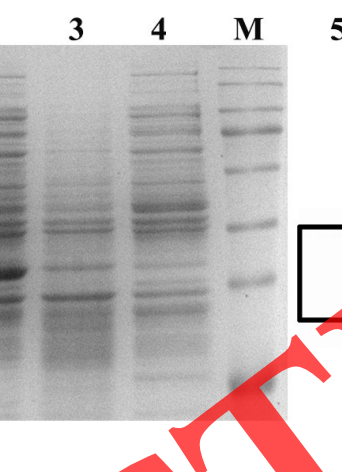

$\begin{array}{lll}6 & 7 & 8\end{array}$

a)

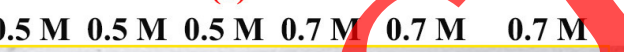

$\mathrm{NaCl}-\mathrm{PB}$

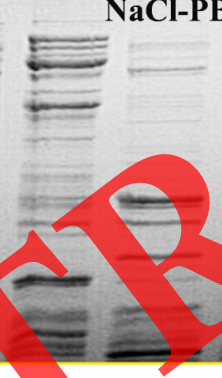

NaCl-PB

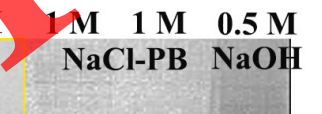

(b)

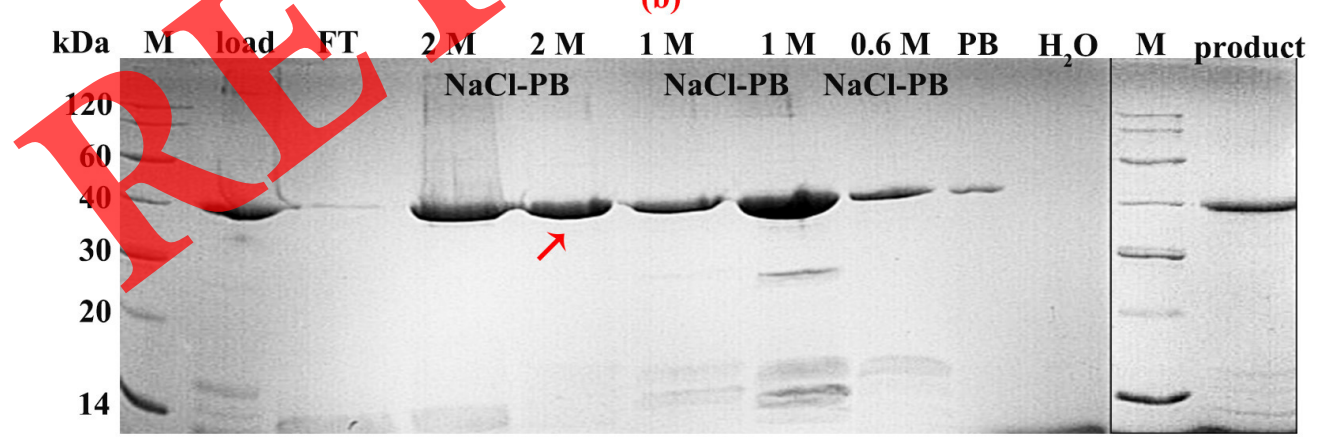

FIGURE 1 | Schematic representation of the recombinant pET28a-Peptibody and the expression and purification tests. (A) The synthesized sequences of bFGFNEGFA and Fc domain with linkers were inserted into pET28a by restriction enzymes Nhel, BamHI, and Xhol. (a) Construction of the prokaryotic expression vector. (b) Combination diagram of the peptide candidates and linkers. (B) Identification of the recombinant vector and expression of Peptibody. (a) Agarose gel of restriction digestion and PCR assays. Lanes 1 and 2, digestion and PCR product of bFGFNEGFA and Fc domain. M, DNA ladder marker. (b) SDS-PAGE and Western blotting assays. Lanes 1 and 2 and 7 and 8 , induction sample. Lanes 3 and 5, non-induction sample. Lanes 4 and 6 , empty vector sample. The primary antibody was monoclonal anti-human VEGFA of rabbit. M, MW marker. (C) The purification procedures of Peptibody. (a) Cation-exchange chromatography. Lanes from left to right, load sample, FT, 0.5 M NaCl-PB, 0.7 M NaCl-PB, $1 \mathrm{M} \mathrm{NaCl-PB}$, and 0.5 M NaOH. (b) Hydrophobic chromatography. Lanes from left to right, load sample, FT, $2 \mathrm{M}$ $\mathrm{NaCl}-\mathrm{PB}, 1 \mathrm{M} \mathrm{NaCl}-\mathrm{PB}, 0.6 \mathrm{M} \mathrm{NaCl}-\mathrm{PB}, 20 \mathrm{mM}$ PB, dd $\mathrm{H}_{2} \mathrm{O}$, and the purified product. FT, flow through; $\mathrm{M}, \mathrm{MW}$ marker. The target protein was $37.4 \mathrm{kDa}$ in which the red arrow pointed at. 


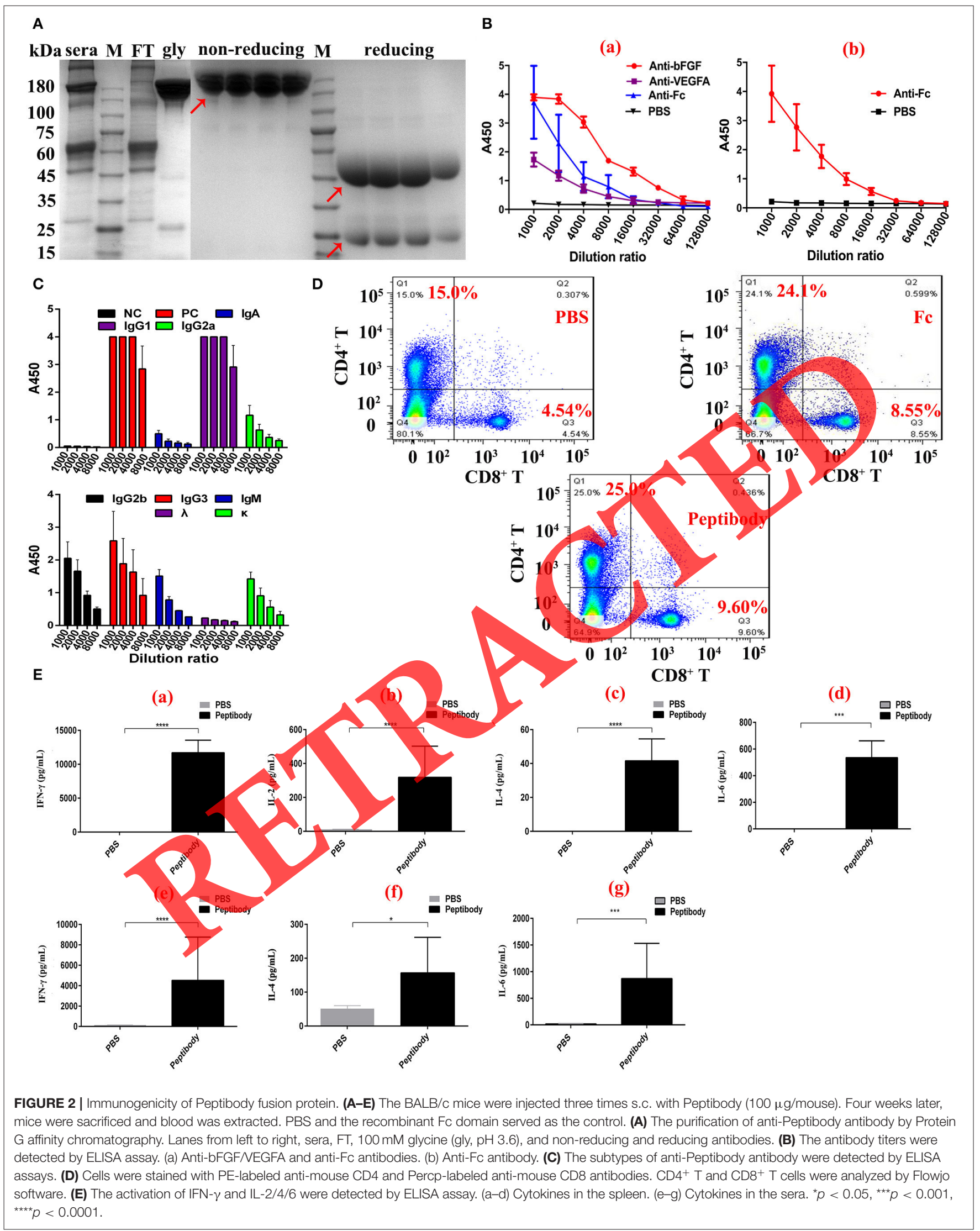


the positive control anti-full-length bFGF antibody. The results suggested that the anti-Peptibody antibody could inhibit the progression of tumor and vascular endothelial cells in vitro.

\section{Peptibody Inhibited the Tumor Growth and Angiogenesis of Lung Cancer and Promoted Survival in Mice}

The C57BL/6 mice $(n=7)$ were pre-immunized with Peptibody and LL- 2 cells $\left(2 \times 10^{6} /\right.$ mouse $)$ were inoculated under the left front flank. Tumor growth of the challenged mice was suppressed by $77.31 \%$ and the life span was prolonged by 12 days, with a median survival time of 33 days (Figure 4A). The generation of microvessels and lymph vessels was decreased by 49.83 and $69.31 \%$, respectively (Figure $4 B$ ). The lung cancer markers in the serum including AFP, NSE, FER, CA50, CA125, CA153, and CA199 were in the range of threshold permitted, which means that the tumor metastasis did not occur (Table S2). In the tumor tissues, the expression levels of bFGF, VEGFA, and PDGF were down-regulated owing to Peptibody immunization (Figure 4C). Activation of the MAPK/Akt/mTOR signal pathways and the MDSCs/TAMsrelated cytokines in TME were obviously blocked, including IL-10, TGF- $\beta$, EGF, and VEGFA (Figure 5). All the inhibitory effects of Peptibody were stronger than the positive control, full-length bFGF. The results suggested that Peptibody could significantly suppress the tumor growth and angiogenesis of lung cancer through blockade of the MAPK/Akt/mTOR signal pathways and suppressive cells in TME. Without alternative activation, the life span of the challenged mice was well-improved.

\section{Primary Structure Determination of Peptibody by Sequencing and Peptide-Mapping Analysis}

For recombinant protein, the composition of N-terminal, Cterminal, and peptide mapping, which is closely related to biological functions, should be totally certified, using Edman degradation and LC-MS. Peptibody was treated with six proteolytic enzymes (trypsin, chymotrypsin, Asp-N, Glu-C, Lys$\mathrm{C}$, and Lys-N) and digested into amenable peptide fragments for LC-MS analysis. The results showed that the 15 amino acids of N-terminal were Met-Gln-Lys-Arg-Lys-Arg-Lys- LysSer-Arg-Tyr-Lys-Ser-Gly-Gly (Figure S2) and that of C-terminal was Lys (K, Table S3), the same as the theoretical sequence. With more proteases, the whole sequence was detected at the coverage of trypsin $87.5 \%$, chymotrypsin $75.3 \%$, and Glu-C $76.7 \%$ (Table S4). The peptide mapping was shown in Figure S3 and Table S5, which could be used as a valuable standard to certify the complete expression and primary structure of Peptibody (29). The pI and MW were 8.93 and $37.415 \mathrm{kDa}$, within the errors allowed (Figures S4A,B). The binding specificity after production was analyzed using anti-VEGFA and anti-His antibodies (Figure S4C).

\section{Secondary Structure Determination of Peptibody by CD Scanning}

$\mathrm{CD}$ instrument has become a valuable technique to estimate the structure of unknown protein specially in the solution. Structures of various types give rise to a characteristic shape and magnitude of CD spectra (30). The secondary structure composition was estimated by CD scanning to further understand the Peptibody biological immunogenicity. The data confirmed the presence of alpha helix (9.0\%), anti-parallel $(31.3 \%)$, parallel $(5.4 \%)$, beta sheet $(22.2 \%)$, and random coil $(39.1 \%)$ in the secondary structure, indicating a better immunogenicity of Peptibody (Figure 6A and Table S6).

\section{Assessing the Stability of Peptibody}

For thermostability, the Tm and Tagg of Peptibody were simultaneously determined by OPTIM instrument. The fluorescence intensity from tryptophane and SLS will be strengthened if proteins unfold and aggregate with temperature going up. The data confirmed the presence of four $\operatorname{Tm}(33.5 \pm$ $0.44,49.7 \pm 0.86,71.3 \pm 0.38$, and $80.9 \pm 1.80^{\circ} \mathrm{C}$ ) and one Tagg $\left(69.2 \pm 0.47^{\circ} \mathrm{C}\right)$, which means that Peptibody started to unfold at $33.5 \pm 0.44^{\circ} \mathrm{C}$, aggregate at $69.2 \pm 0.47^{\circ} \mathrm{C}$, and totally degraded at the temperature over $90^{\circ} \mathrm{C}$ (Figure 6B and Table S7). The substantial thermostability of Peptibody could bring convenience to its preparation research in the following SDS-PAGE, Western blotting, and ds-ELISA assays. The samples and binding activity started to break down at the temperature over $37^{\circ} \mathrm{C}, \mathrm{pH}$ below 4 or over 9 . As for buffer and stabilizer, Tris- $\mathrm{HCl}$ and sucrose were unsuitable (Figure S5). The results suggested that Peptibody could be produced at room temperature $\left(<28^{\circ} \mathrm{C}\right)$ but at least stored at $4^{\circ} \mathrm{C}$. The buffer was normal saline (NS, pH 7.4) for human use but the stabilizer and expiration time of Peptibody needed further examinations.

\section{Assessing the Toxicity of Peptibody}

As for agents from gene engineering, most of the costs are sunk into failures owing to safety findings. Thus, the safety and side effects of Peptibody should be systemically evaluated (31). The regular observation and blood of the Peptibody-immunized mice were collected. The organs including heart, liver, spleen, lung, kidney, hystera, and spermary were analyzed by HE staining. The results showed that no differences of feeding, water drinking, and body weight were found compared with the control (Figure S6A). The blood routines were in the range of threshold permitted (Table S8). Additionally, histamine, an indicator to allergy, was maintained at a low level (Figure S6B). The cell morphology of each organ was healthy and no inflammatory cell infiltration was observed (Figure S7). Therefore, Peptibody had little pathological side effects in mice, but its safety was essential for further observation. These findings might provide pre-clinical evidence to support the potential application of Peptibody in cancer therapy.

\section{DISCUSSION}

For peptide candidates of Peptibody, the antigenic index and secondary structure were crucial in the prediction. We selected 

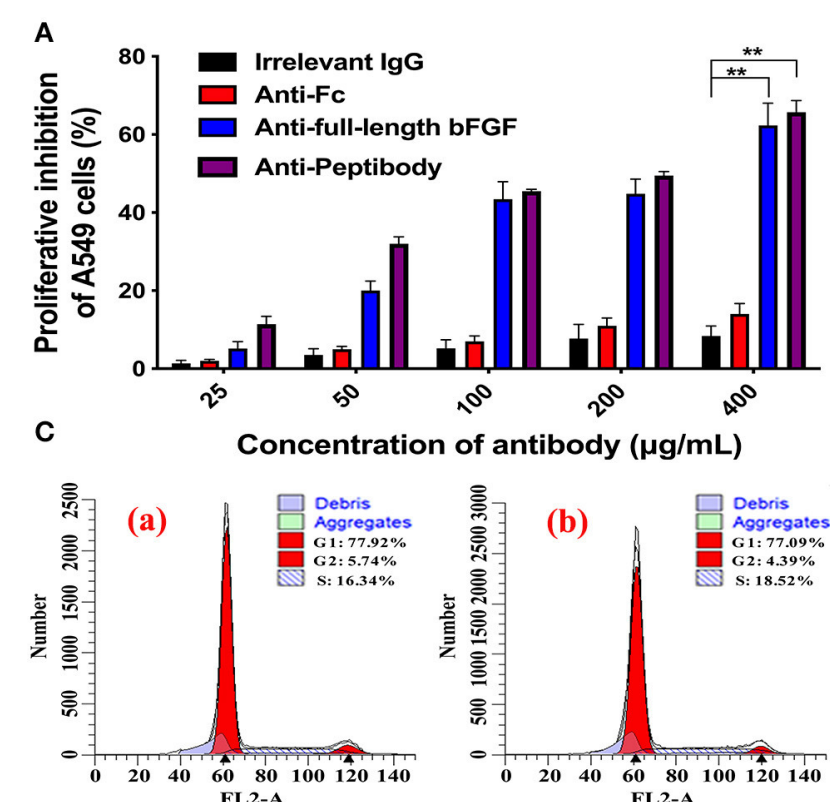

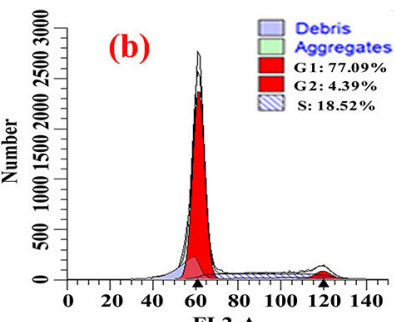

B

$\begin{array}{llllllllllllllll}\text { Time (h) } & 1 & 1 & 1 & 1 & 1 & 1 & 1 & \text { Time (h) } & 0 & 0 & 1 & 3 & 6 & 9 & 12\end{array}$

bFGF -++++++ bFGF

(ng/mL) $-25 \quad 50-100 \quad 200-400 \quad(\mathrm{ng} / \mathrm{mL})$

$50 \quad 100 \quad 200 \quad 400 \quad$ Antibody

$(289 \mathrm{kDa})$

p-Akt

(60 kDa)

$\mathrm{Akt}$
$(60 \mathrm{kDa})$

(60 kDa)

$\underset{(42 / 44 \mathrm{kDa})}{\mathrm{p}-\mathrm{MAPK}}= \pm \equiv= \pm$

$\square--\cdots \cdots$

(

mTOR P N

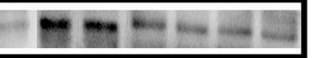

p-Akt

$20-20$

(60 kDa)

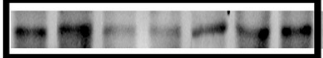

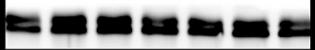

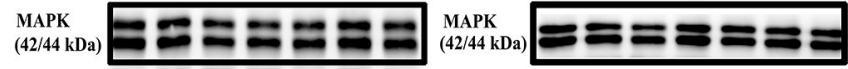

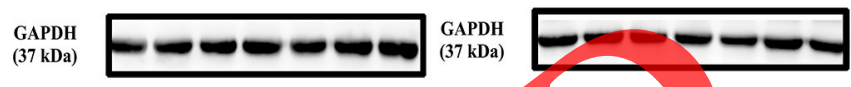

$\mathbf{E}$
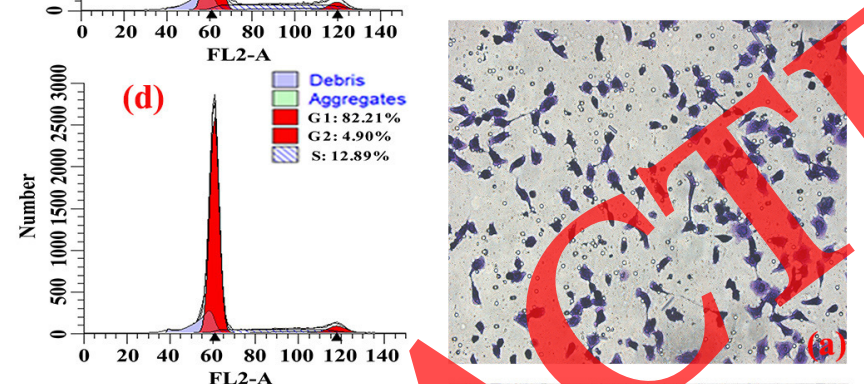

$24 \mathrm{~h}$

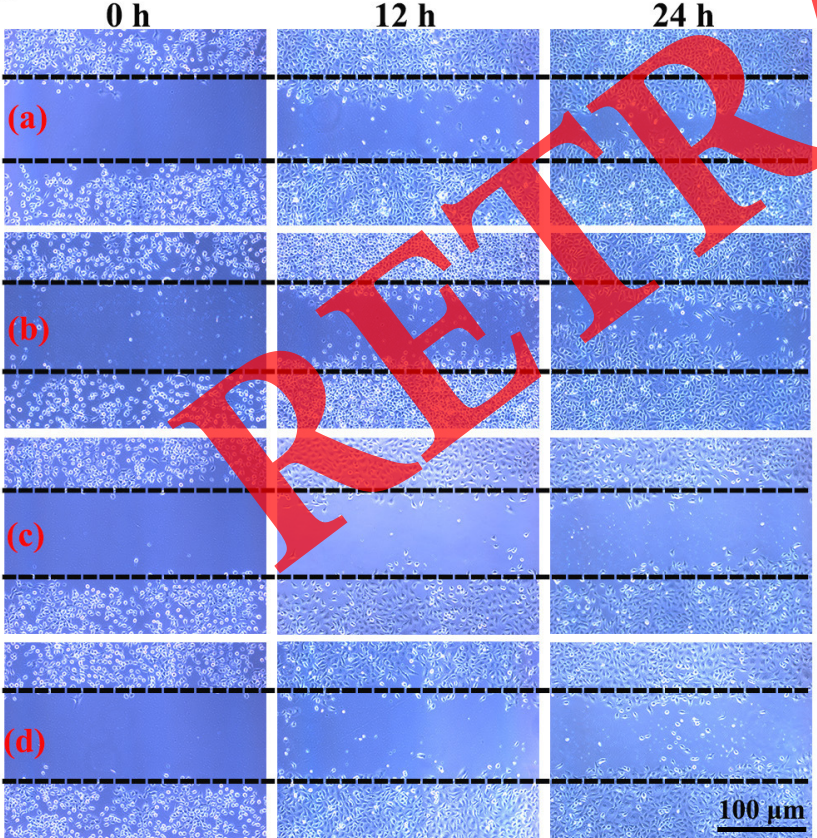

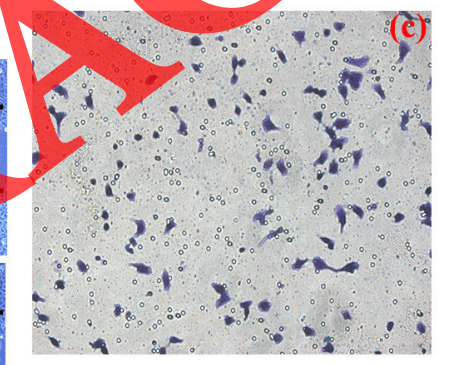

$\mathbf{F}$

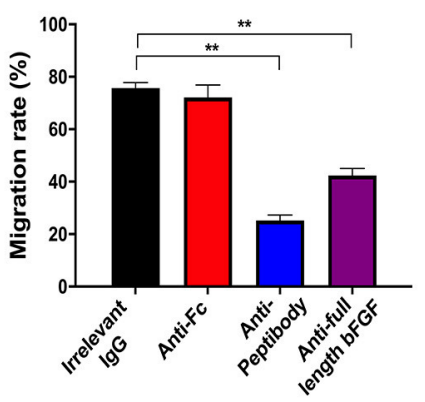

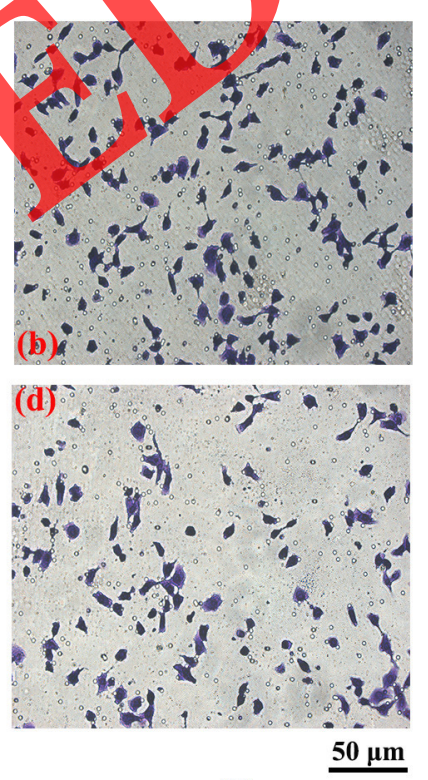

(b)

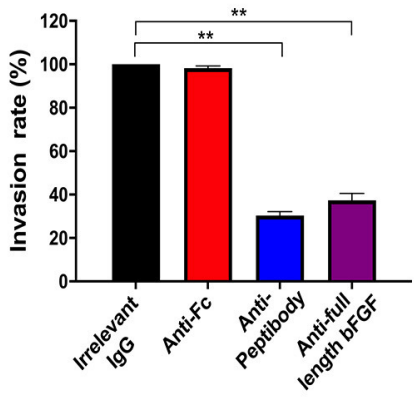

FIGURE 3 | Inhibitory effects of anti-Peptibody antibody on the proliferation, migration, and invasion of A549 cells. (C-E) A549 cells were treated with $200 \mu \mathrm{g} / \mathrm{ml}$ antibodies for $24 \mathrm{~h}$. (a) Irrelevant IgG. (b) Anti-Fc. (c) Anti-Peptibody. (d) Anti-full-length bFGF. (A) A549 cells were treated with increasing concentration of antibodies, and cell viability was determined by CCK-8 assay. (B) MAPK, Akt, and mTOR expression and/or activation were evaluated in A549 cells treated with anti-Peptibody antibody. (a) In a dose-dependent manner. (b) In a time-dependent manner. Expression levels of MAPK, Akt, mTOR, and GAPDH were detected, respectively. Phosphorylation of MAPK and Akt ( $\mathrm{p}-\mathrm{MAPK}$ and $\mathrm{p}$-Akt) was detected, as indicated. GAPDH served as loading control. Total proteins of each sample (20 $\mu \mathrm{g}$ ) were 
FIGURE 3 | analyzed by SDS-PAGE. (C) Cells were stained with PI and cell cycle phase distribution was analyzed by ModiFit software. (D) The effect of anti-Peptibody antibody on A549 cell migration was measured by wound-healing assay. Representative images showed the scratched areas of A549 cells. (E) The effect of the anti-Peptibody antibody on A549 cell invasion was measured by transwell chamber assay. Representative images showed the invaded A549 cells. (F) (a, b) Statistical analysis of A549 cell migration and invasion data. Scale bars, D: $100 \mu \mathrm{m}$, E: $50 \mu \mathrm{m}$. ${ }^{\star \star} p<0.01$.

B cells and T cell epitopes of human bFGF/VEGFA, and in CD scanning, the epitopes were abundant in alpha helix, anti-parallel, parallel, beta sheet, and random coil. The effector peptides fused with Fc domain are highly immunogenic to induce immune responses, relative to native antigens (32). The Peptibody we designed could elicit high-titer anti-bFGF/VEGFA antibodies, $\mathrm{T}$ cells, and Th1/Th2-type cytokine activation in mice, suggesting that it could stimulate specific humoral and cellular immune responses. Meanwhile, it was possible that the immune responses to Peptibody might be dependent on the sequence differences between human and mice. If so, the Peptibody fusion protein can be recognized as foreign antigens and induce antibodies in mice, but may be recognized as self-antigen in human. To rule out this suspicion, clinical trials are needed. According to NCBI matching, the epitopes we selected are so similar to murine bFGF/VEGFA, only one to three different amino acids, that it is expected to elicit dramatic immune responses in human body when it occurs in mice. In case of failure, the fusion protein targeting both bFGF/VEGFA is still promising, because, in turn, we can use peptide candidates of other species to elicit immune responses in clinical trials.

Lung cancer, full of neovascularization, is the most commonly diagnosed cancer with the highest mortality rate (33). bFGF and VEGFA were highly expressed in A549 and LL-2 cells (34, 35). Consequently, the tumor growth and angiogenesis oflung cancer were obviously suppressed by Peptibody immunization. It has been reported that the expression levels of PDGF and DEGF will be increased in the patients with long-tem use of Bevacizumab, followed by a compensatory restoration of angiogenesis (36). In the mice immunized with full-length bFGF alone, VEGFA was up-regulated compared with PBS immunization while PDGF was up-regulated compared with Peptibody immunization. The expression levels of 6 FGF and VEGFA were reduced and we did not see altemative activation of PDGF in the tumor sites immunized with Peptibody (Figure 4C). It is necessary that alternative activation of any other related angiogenic factors should be identified in the following experiments. Therefore, the strategy targeting both bFGF and VEGFA signal pathways may help strengthen the therapeutic efficacy of tumor patients and relieve the resistance (37).

We believe that the mouse anti-human bFGF/VEGFA antibodies elicited by Peptibody can neutralize the dissociative murine bFGF/VEGFA in tumor microenvironment (TME) and the pathways related in the tumor cells will be downregulated, resulting in tumorigenesis and angiogenesis inhibition. The anti-Peptibody antibodies isolated from the serum were polyclonal antibodies, including anti-bFGF/VEGFA and Fc antibodies. Although immunization with the recombinant Fc domain alone could also activate some immune responses in mice, the anti-Fc antibody did not show any inhibitory effects on tumor progression and angiogenesis in vitro. Thus, the inhibitory effects were more specific due to antibodies against the bFGF/VEGFA epitopes we designed. However, the antibFGF/VEGFA antibodies may or may not be against all the six peptide candidates and some of them may not work. We are not sure which epitopes are responsible for the inhibitory effects. Hence, we are planning to immunize the epitopes independently so that we can figure out the specific epitopes and improve the fusion protein.

Activation of FGFR and VEGFR can trigger downstream MAPK/Akt signal pathways, which play key roles in the behaviors of tumor and endothelial cells including proliferation, survival, and motility $(38,39)$. Moreover, the Akt signal pathway positively regulates $\mathrm{mTOR}$, which has been associated with bad prognosis and earlier recurrence in tumor treatment (40). In particular, the mTOR inhibitor rapamycin has showed potent anti-tumor effects (41). The activation of MAPK/Akt/mTOR signal pathways were simultaneously down-regulated when treated with anti-Peptibody antibody in A549 cells, HUVECs, and Peptibody in LL-2-bearing mice. The cellular events of tumor and endothelial cells were suppressed, following tumorigenesis and neovascularization depression. However, our knowledge about the inhibition is still very limited, especially regarding, the mechanism of down-regulating downstream signal pathways and gene expression for tumorigenesis and angiogenesis.

Although immunotherapeutic approaches have been approved in several tumors, the anti-tumor efficacy appears to be modest in clinical therapy (42). This tumor resistance might be partly related to the highly immunosuppressive TME (43). The immunoregulatory mechanisms responsible for tumor escape have been identified and what we pay the most attention to is the activation of suppressive cells including myeloid-derived suppressor cells (MDSCs) and tumor-associated macrophages (TAMs) $(44,45)$. VEGFA and other factors activate MDSCs $\left(\mathrm{Gr}-1^{+} \mathrm{CD} 11 \mathrm{~b}^{+}\right)$to suppress host immune responses, enhance angiogenesis, and promote tumorigenesis through secretion of versatile immunosuppressive factors, such as IL-10 and TGF- $\beta$ (46). The IL-4-activated TAMs (M2 phenotype, $\mathrm{CD}_{11} \mathrm{~b}^{+} \mathrm{CD} 11 \mathrm{c}^{-}$) enhance the malignancy of tumor cells by releasing a variety of cytokines, including EGF and VEGFA (47). With Peptibody immunization, the $\mathrm{CD}_{11} \mathrm{~b}^{+}$cells and related cytokines of suppressive cells were obviously down-regulated, suggesting that Peptibody could destroy the immunosuppressive TME and produce dramatic inhibitory effects on tumor growth and angiogenesis.

The recombinant protein fused with Fc domain conferred certain advantages to stability. Peptibody occurred to degrade and aggregate at higher temperature, which would cut the costs for production, transportation, and storage. Moreover, Peptibody 


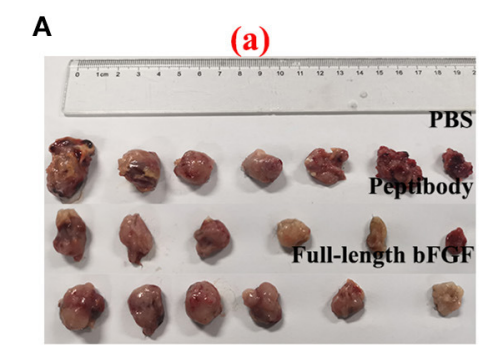

B
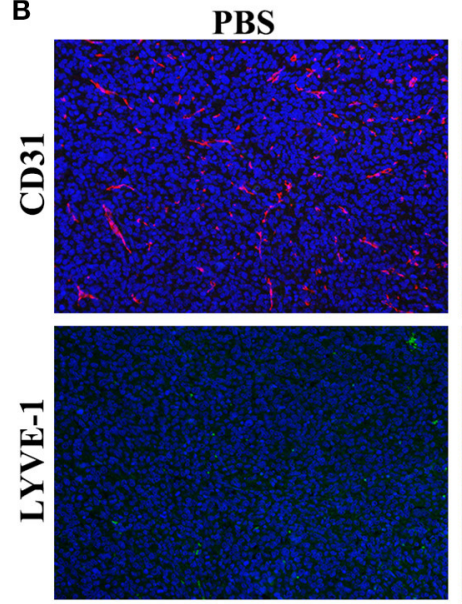

C
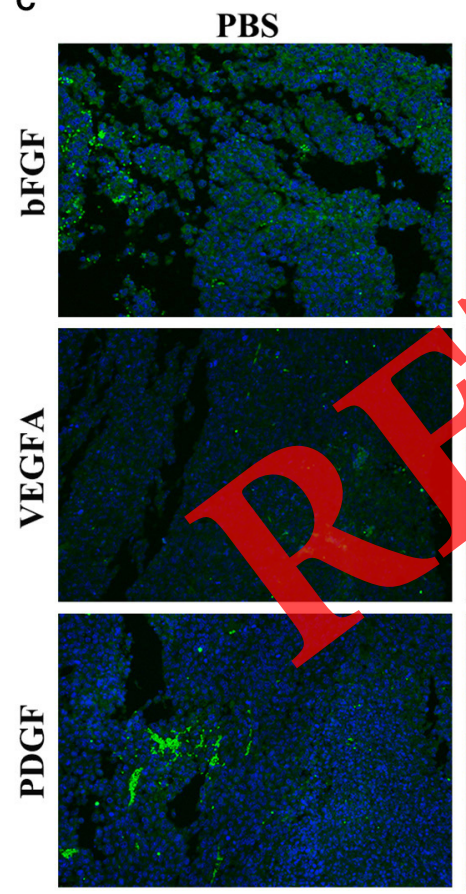

(b)

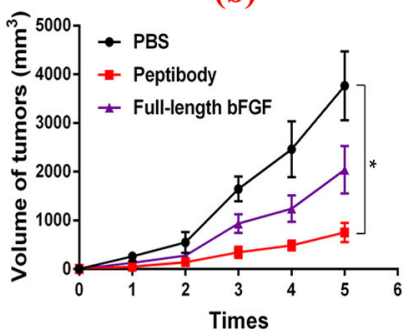

Peptibody
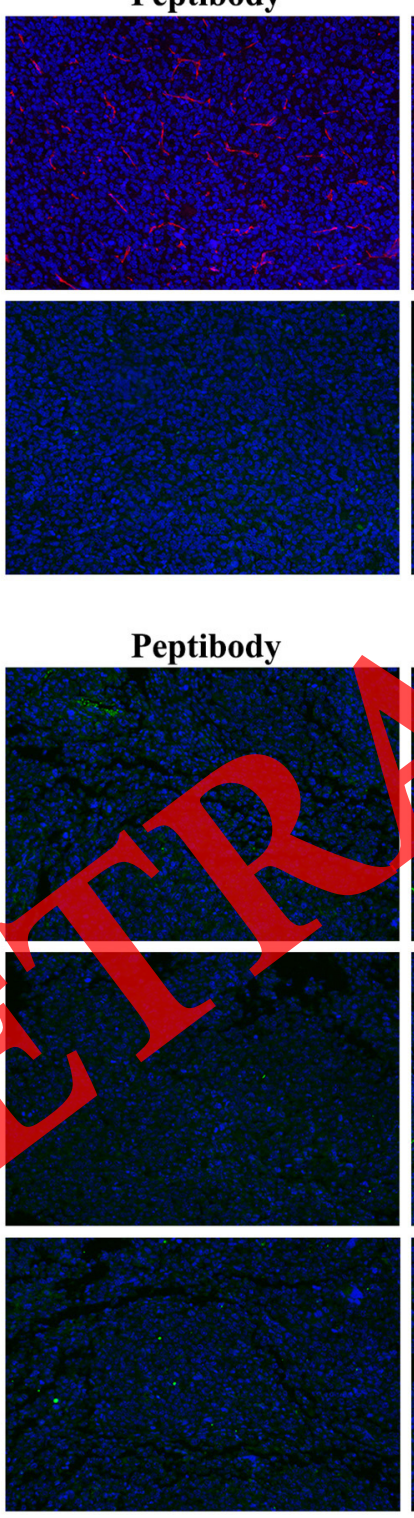

(c)

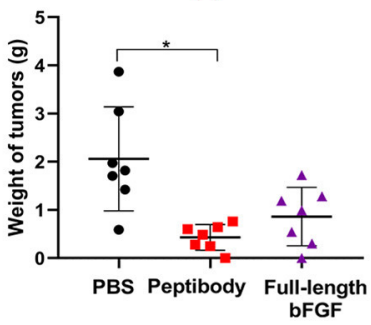

Full-length bFGF
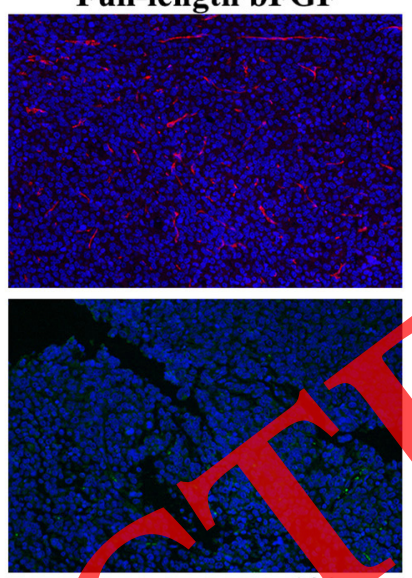

$100 \mu \mathrm{m}$

Full-length bFGF
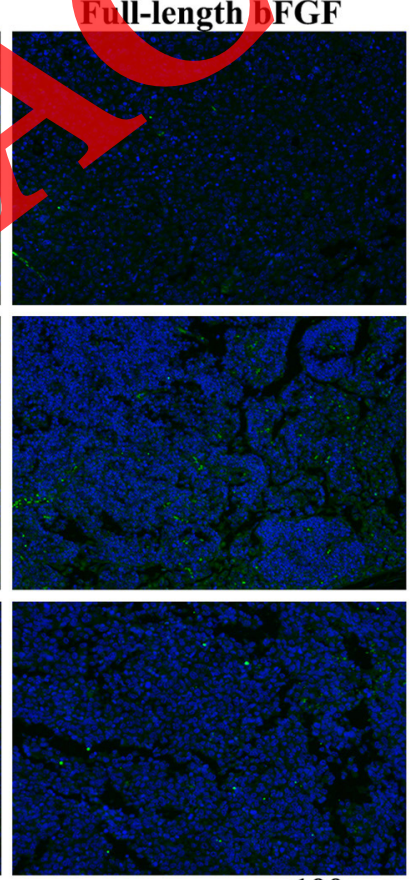

$100 \mu \mathrm{m}$
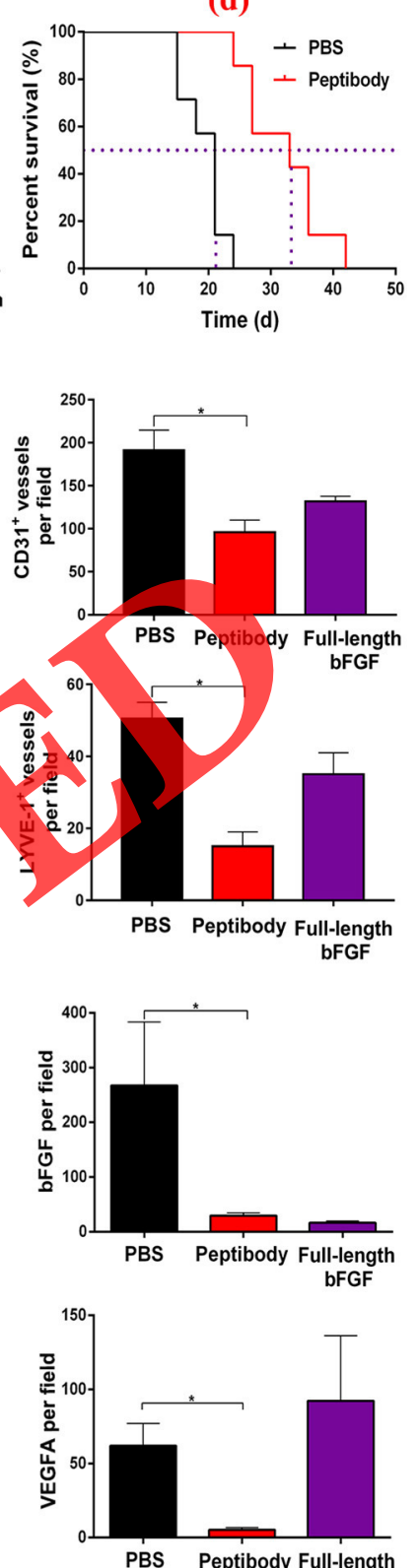

PBS Peptibody Full-length bFGF

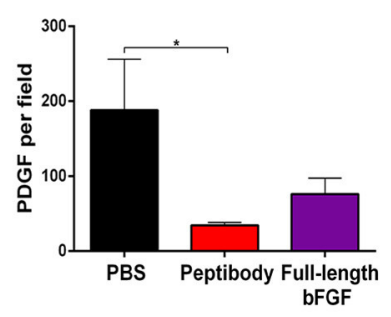

FIGURE 4 | Inhibitory effects of Peptibody on the tumor growth and angiogenesis in mice and the survival promotion. (A-C) C57BL/6 mice $(n=7)$ were s.c. given injection of Peptibody (100 $\mu \mathrm{g} /$ mouse), human full-length bFGF (100 $\mu \mathrm{g} / \mathrm{mouse})$, and the same volume of PBS for three times, respectively. Four weeks later, LL-2 cells $\left(2 \times 10^{6}\right.$ /mouse) were inoculated under the left front flank. (A) (a) Tumor images. (b) Tumor volume. (c) Tumor weight. (d) Survival time. (B,C) IF staining of microvessels, lymph vessels, and angiogenic factors of the stripped tumors. Left panel, representative images. Right panel, statistical analysis of data. Scale bars, B: $100 \mu \mathrm{m}, \mathrm{C:}: 100 \mu \mathrm{m} .{ }^{*} p<0.05$. 


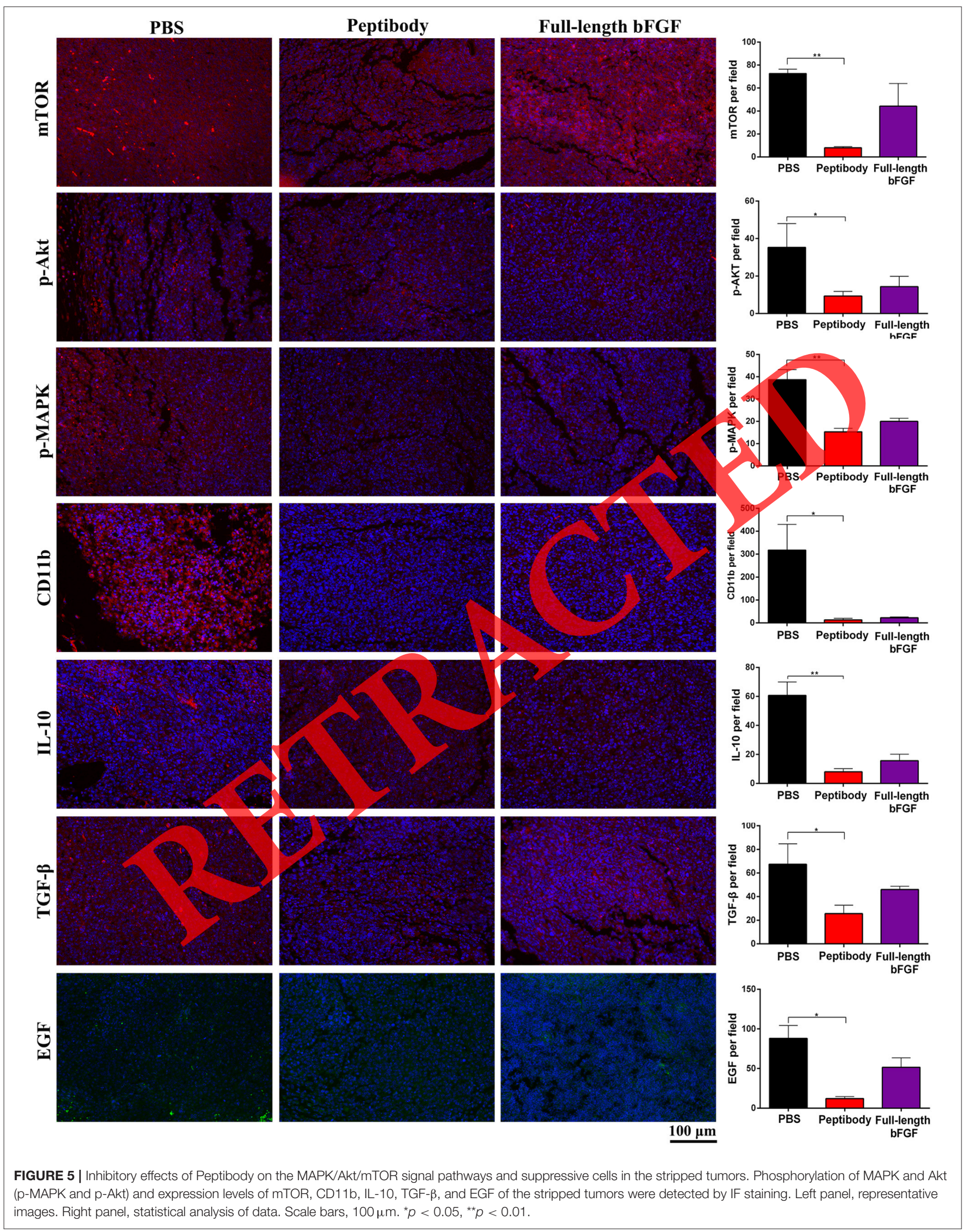




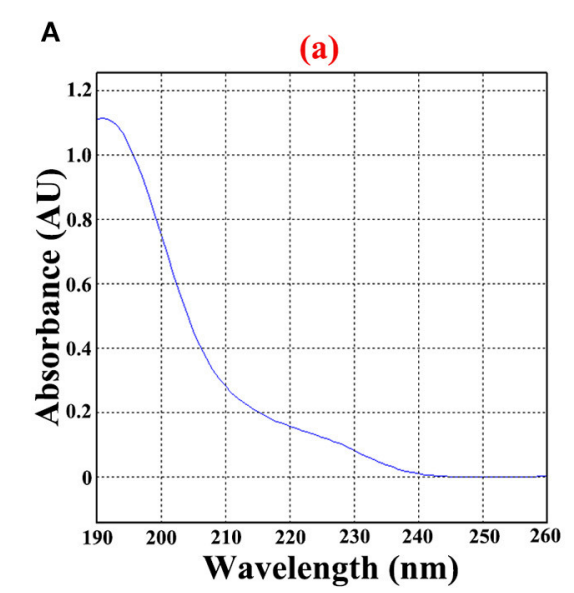

(d)

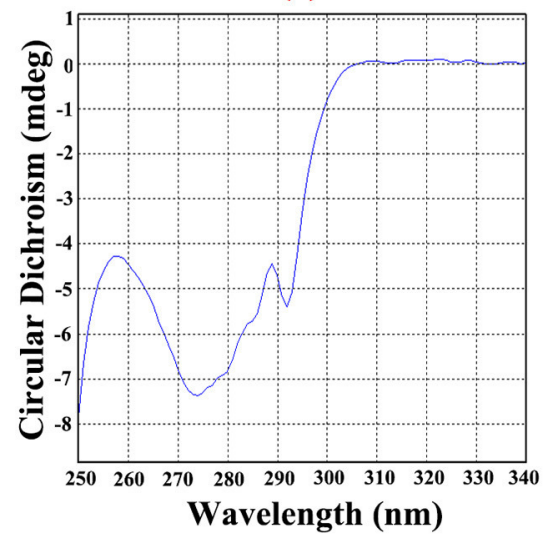

B

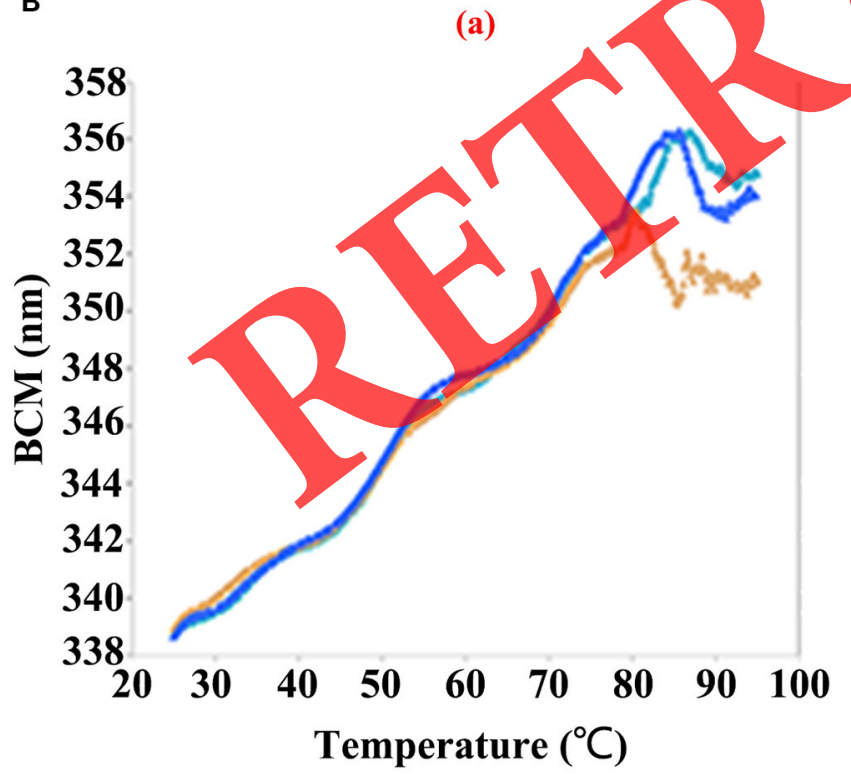

(b)

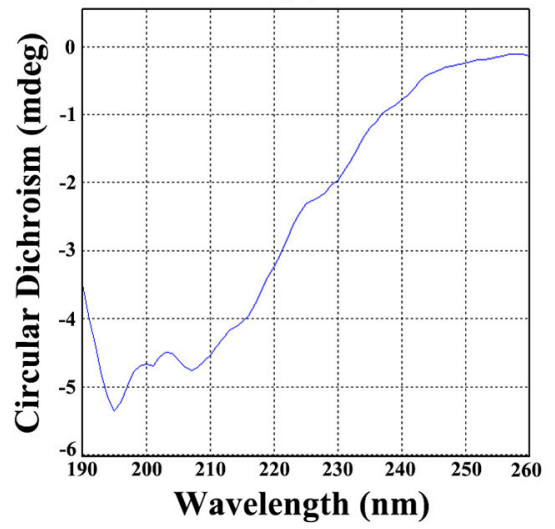

(e)

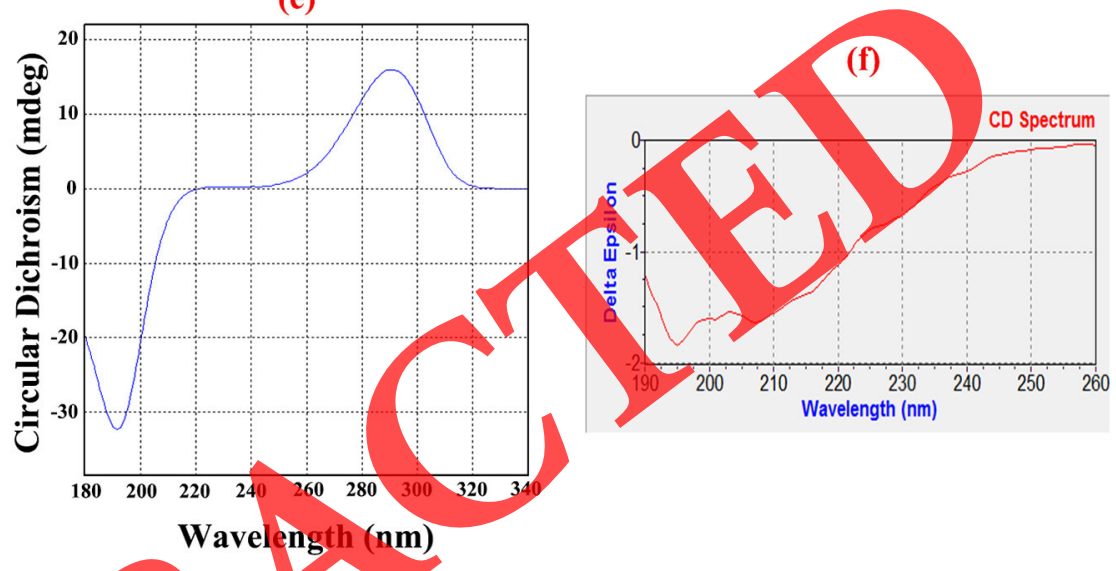

(b) (c)

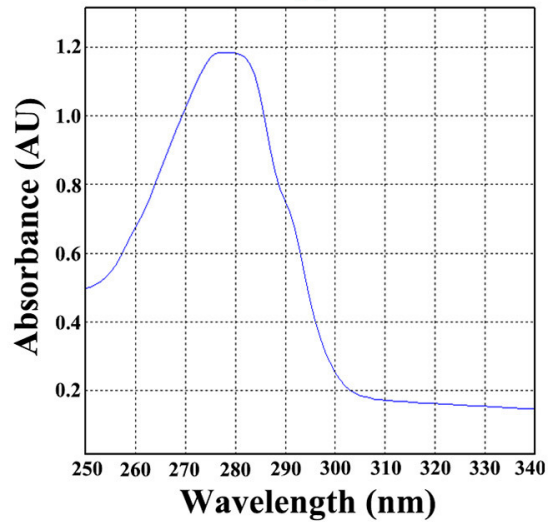


exhibited favorable stability in common buffers and stabilizers, expecting a longer half-life and a better efficacy. Fortunately, little side effects of organs, allergy, and survival were detected, but more toxicity examinations should be performed, such as the inhibitory effects of Peptibody on normal wound healing and other toxicity evaluation.

\section{CONCLUSIONS}

In conclusion, this study developed a multi-epitope Peptibody with bFGF/VEGFA, which consisted of three human bFGF peptides and three human VEGFA peptides with human IgG1 Fc domain. Immunization with Peptibody could induce high-titer anti-bFGF/VEGFA antibodies, activate $\mathrm{T}$ cells, and induce Th1/Th2 type cytokines. The anti-Peptibody antibody inhibited the proliferation and migration of A549 cells and HUVECs by decreasing the MAPK/Akt/mTOR signal pathways. In murine model, pre-immunization with Peptibody suppressed tumor growth and angiogenesis to promote survival time. Additionally, the primary and secondary structures of Peptibody were systematically detected. With satisfactory stability and toxicity, the Peptibody fusion protein targeting both bFGF and VEGFA may provide a broad-acting therapeutic modality for tumor angiogenesis.

\section{DATA AVAILABILITY STATEMENT}

The datasets presented in this study can be found in online repositories. The names of the repository/repositories and accession number(s) can be found below: FigShare, https://doi. org/10.6084/m9.figshare.12444770.v1.

\section{ETHICS STATEMENT}

The animal study was reviewed and approved by Institutional Animals Care and Use Committee on animal research in Jinan University, Guangzhou, China.

\section{AUTHOR CONTRIBUTIONS}

LZ and YD designed and performed the experiments and drafted the manuscript. YZ, CL, SZ, and WZ participated in the experiments. ND and YT supervised this study. All authors read and approved the final manuscript.

\section{FUNDING}

This work was supported by the grants from the State Natural Science Foundation of China (Grant No. 81972705 to ND), the Science and Technology Planning Project of Guangdong Province (2015B020211009 and 2016A010105008 to ND), and the Science and Technology Planning Project of Guangzhou City (201604020099 to ND)

\section{ACKNOWLEDGMENTS}

Rong Li, Weibiao Liang, and Qifang Song were involved in resource collection.

\section{SUPPLEMENTARY MATERIAL}

The Supplementary Material for this article can be found online at: https://www.frontiersin.org/articles/10.3389/fonc. 2020.01190/full\#supplementary-material

\section{REFERENCES}

1. Carmeliet P, Jain RK. Principles and mechanisms of vessel normalization for cancer and other angiogenic diseases. Nat Rev Drug Disco. (2011) 10:41727. doi: $10.1038 / \mathrm{nrd} 3455$

2. Batlle R, Andrés E, Gonzalez L, Llonch E, Igea A, Gutierrez-Prat N, et al. Regulation of tumor angiogenesis and mesenchymal-endothelial transition by $38 \alpha$ through TGF- $\beta$ and JNK signaling. Nat Commun. (2019) 10:118. doi: 10.1038/s41467-019-10946-y

3. Kishimoto K, Liu S, Tsuji T, Olson KA, Hu GF. Endogenous angiogenin in endothelial cells is a general requirement for cell proliferation and angiogenesis. Oncogene. (2005) 24:445-56. doi: 10.1038/sj.onc.1208223

4. Forbes K, Webb MA, Sehgal I. Growth factor regulation of secreted matrix metalloproteinase and plasminogen activators in prostate cancer cells, normal prostate fibroblasts and normal osteoblasts. Prostate Cancer Prostatic Dis. (2003) 6:148-53. doi: 10.1038/sj.pcan.4500640

5. Hosaka K, Yang Y, Nakamura M, Andersson P, Yang X, Zhang Y, et al. Dual roles of endothelial FGF-2-FGFR1-PDGF-BB and perivascular FGF2-FGFR2-PDGFR $\beta$ signaling pathways in tumor vascular remodeling. Cell Discov. (2018) 4:3. doi: 10.1038/s41421- 017-0002-1

6. Tiseo M, Gelsomino F, Alfieri R, Cavazzoni A, Bozzetti C, De Giorgi AM, et al. FGFR as potential target in the treatment of squamous non small cell lung cancer. Cancer Treat Rev. (2015) 41:527-39. doi: 10.1016/j.ctrv.2015.04.011

7. Perez-Garcia J, Muñoz-Couselo E, Soberino J, Racca F, Cortes J. Targeting FGFR pathway in breast cancer. Breast. (2018) 37:126-33. doi: 10.1016/j.breast.2017.10.014
8. Abou Faycal C, Brambilla E, Agorreta J, Lepeltier N, Jacquet T, Lemaître $\mathrm{N}$, et al. The sVEGFR1-i13 splice variant regulates a $\beta 1$ integrin/VEGFR autocrine loop involved in the progression and the response to antiangiogenic therapies of squamous cell lung carcinoma. Br J Cancer. (2018) 118:1596-608. doi: 10.1038/s41416-018-0128-4

9. Gyanchandani R, Ortega Alves MV, Myers JN, Kim S. A proangiogenic signature is revealed in FGF-mediated bevacizumab-resistant head and neck squamous cell carcinoma. Mol Cancer Res. (2013) 11:1585-96. doi: 10.1158/1541-7786.MCR-13-0358

10. Bogdanovich S, Kim Y, Mizutani T, Yasuma R, Tudisco L, Cicatiello $\mathrm{V}$, et al. Human IgG1 antibodies suppress angiogenesis in a target-independent manner. Signal Transduct Target Ther. (2016) 1:15001. doi: 10.1038/sigtrans.2015.1

11. Wilke H, Muro K, Van Cutsem E, Oh S-C, Bodoky G, Shimada Y, et al. Ramucirumab plus paclitaxel versus placebo plus paclitaxel in patients with previously treated advanced gastric or gastro-oesophageal junction adenocarcinoma (RAINBOW): a double-blind, randomised phase 3 trial. Lancet Oncol. (2014) 15:1224-35. doi: 10.1016/S1470-2045(14)70420-6

12. Van Cutsem E, Tabernero J, Lakomy R, Prenen H, Prausová J, Macarulla $\mathrm{T}$, et al. Addition of aflibercept to fluorouracil, leucovorin, and irinotecan improves survival in a phase III randomized trial in patients with metastatic colorectal cancer previously treated with an oxaliplatin-based regimen. J Clin Oncol. (2012) 30:3499-506. doi: 10.1200/jco.2012.42.8201

13. Motzer RJ, Michaelson MD, Redman BG, Hudes GR, Wilding G, Figlin RA, et al. Activity of SU11248, a multitargeted inhibitor of vascular endothelial growth factor receptor and platelet-derived growth factor receptor, in 
patients with metastatic renal cell carcinoma. J Clin Oncol. (2006) 24:1624. doi: 10.1200/JCO.2005.02.2574

14. Escudier B, Eisen T, Stadler WM, Szczylik C, Oudard S, Staehler M, et al. Sorafenib for treatment of renal cell carcinoma: Final effificacy and safety results of the phase III treatment approaches in renal cancer global evaluation trial. J Clin Oncol. (2009) 27:3312-18. doi: 10.1200/JCO.2008.19.5511

15. Sternberg CN, Davis ID, Mardiak J, Szczylik C, Lee E, Wagstaff J, et al. Pazopanib in locally advanced or metastatic renal cell carcinoma: Results of a randomized phase III trial. J Clin Oncol. (2010) 28:10618. doi: 10.1200/JCO.2009.23.9764

16. Bergers G, Hanahan D. Modes of resistance to anti-angiogenic therapy. Nat Rev Cancer. (2008) 8:592-603. doi: 10.1038/nrc2442

17. Suzuki S, Annaka H, Konno S, Kumagai I, Asano R. Engineering the hinge region of human IgG1 Fc-fused bispecific antibodies to improve fragmentation resistance. Sci Rep. (2018) 8:17253. doi: 10.1038/s41598-018-35489-y

18. Kumar M, Hunag Y, Glinka Y, Prud'Homme GJ, Wang Q. Gene therapy of diabetes using a novel GLP-1/IgG1-Fc fusion construct normalizes glucose levels in $\mathrm{db} / \mathrm{db}$ mice. Gene Ther. (2007) 14:162-72. doi: 10.1038/sj.gt.33 02836

19. Scott LJ. Etanercept: a review of its use in autoimmune inflammatory diseases. Drugs. (2014) 74:1379-410. doi: 10.1007/s40265-014-0258-9

20. Roopenian DC, Akilesh S. FcRn: the neonatal Fc receptor comes of age. Nat Rev Immunol. (2007) 7:715-25. doi: 10.1038/nri2155

21. Levin D, Golding B, Strome SE, Sauna ZE. Fc fusion as a platform technology: potential for modulating immunogenicity. Trends Biotechnol. (2015) 33:2734. doi: 10.1016/j.tibtech.2014.11.001

22. Fu Y, Zhang Z, Sheehan J, Avnir Y, Ridenour C, Sachnik T, et al. A broadly neutralizing anti-influenza antibody reveals ongoing capacity of haemagglutinin-specific memory B cells to evolve. Nat Commun. (2016) 7:12780. doi: $10.1038 /$ ncomms 12780

23. Ultee ME. Therapeutic Fc-fusion proteins. MAbs. (2014) 6:8101. doi: $10.4161 /$ mabs. 28832

24. Czajkowsky DM, Hu J, Shao Z, Pleass RJ. Fc-fusion proteins: new developments and future perspectives. EMBO Mol Med. (2012) 4:101528. doi: 10.1002/emmm.201201379

25. Huang C. Receptor-Fc fusion therapeutics, MIMETIBODY technology. Curr Opin Biotechnol. 2009) 20:6929. doi: 10.1016/j.copbio.2009.10.010

26. Xiang J, Zhong Z, Deng N, Zhong Z, Yang H. Screening antigen epitope of basic fibroblast growth factor by phage display. J Biochem Mol Biol. (2005) 38:290-3. doi: 10.5483/bmbrep.2005.38.3.2

27. Saha S, Raghava G. BcePred: prediction of continuous B-cell epitopes in antigenic sequences using physico-chemical properties. Artif Immune Syst Proc. (2004) 3239:197-204. doi 10.1007/978 3-540-30220-9/16

28. El-Manzalawy Y, Dobbs D, Honavar V. Predicting linear B-cell epitopes using string kernels. J Mol Recognit. (2008) 21:243-55. do: 10.1002/jmr.893

29. Zhu L, Guo Q, Guo H, Liu T, Zheng Y, Gu P, et al. Versatile characterization of glycosylation modification in CTLA4-Ig fusion proteins by liquid chromatography-mass spectrometry. mAbs. (2014) 6:147485. doi: $10.4161 /$ mabs. 3631

30. Kelly SM, Jess TJ, Price NC. How to study proteins by circular dichroism. Biochim Biophys Acta. (2005) 1751:119-39. doi: 10.1016/j.bbapap.2005.06.005

31. Failli M, Paananen J, Fortino V. Prioritizing target-disease associations with novel safety and efficacy scoring methods. Sci Rep. (2019) 9:111. doi: 10.1038/s41598-019-46293-7

32. Zaharatos GJ, Yu J, Pace C, Song Y, Vasan S, Ho DD, et al. HIV-1 and influenza antigens synthetically linked to IgG2a Fc elicit superior humoral responses compared to unmodified antigens in mice. Vaccine. (2011) 30:4250. doi: 10.1016/j.vaccine.2011.10.056

33. Du T, Li H, Fan Y, Yuan L, Guo X, Zhu Q, et al. The deubiquitylase OTUD3 stabilizes GRP78 and promotes lung tumorigenesis. Nat Commun. (2019) 10:1-15. doi: 10.1038/s41467-019-10824-7
34. Ueno K, Inoue $\mathrm{Y}$, Kawaguchi T, Hosoe S, Kawahara M. Increased serum levels of basic fibroblast growth factor in lung cancer patients: relevance to response of therapy and prognosis. Lung Cancer. (2001) 31:21319. doi: 10.1016/S0169-5002(00)00187-2

35. Young RJ, Tin AW, Brown NJ, Jitlal M, Lee SM, Woll PJ. Analysis of circulating angiogenic biomarkers from patients in two phase III trials in lung cancer of chemotherapy alone or chemotherapy and thalidomide. Br J Cancer. (2012) 106:1153-9. doi: 10.1038/bjc.2012.50

36. Foy KC, Miller MJ, Moldovan N, Carson WE, Kaumaya PTP. Combined vaccination with HER-2 peptide followed by therapy with VEGF peptide mimics exerts effective anti-tumor and anti-angiogenic effects in vitro and in vivo. OncoImmunology. (2012) 1:1048-60. doi: 10.4161/onci.20708

37. Itatani $\mathrm{Y}$, Kawada K, Yamamoto T, Sakai Y. Resistance to anti-angiogenic therapy in cancer-alterations to anti-VEGF pathway. Int J Mol Sci. (2018) 19:E1232. doi: 10.3390/ijms19041232

38. Ornitz DM, Itoh $\mathrm{N}$. The fibroblast growth factor signaling pathway. Wiley Interdiscip Rev Dev Biol. (2015) 4:215-66. doi: 10.1002/wdev.176

39. Azad T, Janse van Rensburg HJ, Lightbody ED, Neveu B, Champagne A, Ghaffari A, et al. A LATS biosensor screen identifies VEGFR as a regulator of the hippo pathway in angiogenesis. Nat Commun. (2018) 9:1061. doi: 10.1038/s41467-018-03278-w

40. Lin X, Zhang YY, Liu LY, McKeehan WL, Shen YM, Song SY, et al. FRS2alpha is essential for the fibroblast growth factor to regulate the mTOR pathway and autophagy in mouse embryonic fibroblasts. Int J Biol sci. (2011) 7:111421. doi: 10.7150/ijbs.7.1114

41. Matter MS, Decaens T, Andersen JB, Thorgeirsson SS. Targeting the mTOR pathway in hepatocellular carcinoma: current state and future trends. $J$ Hepatol. (2013) 60:855-65. doi: 10.1016/j.jhep.2013.11.031

42. Li X, Liu Z, Zhang A, Han C, Shen A, Jiang L, et al. NQO1 targeting prodnug triggers innate sensing to overcome checkpoint blockade resistance. Nat Commun. (2019) 10:3251.doi: 10.1038/s41467-019-11238-1

43. Altorki NK, Markowitz GJ, Gao D, Port JL, Saxena A, Stiles B, et al. The lung microenvironment: an important regulator of tumour growth and metastasis. Nat Rev Cancer. (2019) 19:9-31. doi: 10.1038/s41568-018-0081-9

$\mathrm{Xu}$ Z, Li L, Qian Y, Song Y, Qin L, Duan Y, et al. Upregulation IL-6 in CUL4B-deficient myeloid-derived suppressive cells ncreases the aggressiveness of cancer cells. Oncogene. (2019) 38:5860-72. doi: 10.1038/s41388-019-0847-x

Chen F, Chen JN, Yang LB, Liu J, Zhang XQ, Zhang Y, et al. Extracellular vesicle-packaged HIF-1 $\alpha$-stabilizing lncRNA from tumourassociated macrophages regulates aerobic glycolysis of breast cancer cells. Nat Cell Biol. (2019) 21:498-510. doi: 10.1038/s41556-0190299-0

46. Kustermann $M$, Klingspor $M$, Huber-Lang $M$, Debatin K-M, Strauss G. Immunostimulatory functions of adoptively transferred MDSCs in experimental blunt chest trauma. Sci Rep. (2019) 9:7992. doi: 10.1038/s41598-019-44419-5

47. Chen J, Yao Y, Gong C, Yu F, Su S, Chen J, et al. CCL18 from tumor-associated macrophages promotes breast cancer metastasis via PITPNM3. Cancer Cell. (2011) 19:541-55. doi: 10.1016/j.ccr.2011. 02.006

Conflict of Interest: The authors declare that the research was conducted in the absence of any commercial or financial relationships that could be construed as a potential conflict of interest.

Copyright (๑) 2020 Zhang, Deng, Zhang, Liu, Zhang, Zhu, Tang and Deng. This is an open-access article distributed under the terms of the Creative Commons Attribution License (CC BY). The use, distribution or reproduction in other forums is permitted, provided the original author(s) and the copyright owner(s) are credited and that the original publication in this journal is cited, in accordance with accepted academic practice. No use, distribution or reproduction is permitted which does not comply with these terms. 